DOI: $10.19195 / 2084-5065.43 .10$

\title{
Tendencje prywatyzacji prawa karnego a ujmowanie społecznej szkodliwości jako podstawy kryminalizacji*
}

\author{
Dagmara Gruszecka \\ Katedra Prawa Karnego Materialnego \\ Uniwersytet Wrocławski
}

Wszechstronność zainteresowań badawczych Profesora Tomasza Kaczmarka, obejmujących pełne spektrum zasadniczych zagadnień karnistycznych zarówno z obszarów tradycyjnie przyporządkowanych nauce o przestępstwie, jak i karze, stanowi znaczną dogodność dla każdego autora zaszczyconego zaproszeniem do podzielenia się własnymi skromnymi uwagami w księdze jubileuszowej, albowiem trudno byłoby wśród istotnych kwestii dogmatyki prawa karnego znaleźć takie, które nie pozwalałyby na nawiązanie do myśli Szanownego Jubilata i czerpanie z nich zawsze aktualnych nauki i inspiracji. Jednak ta wielopłaszczyznowość refleksji i ogrom dorobku naukowego grozi pułapką w tórności lub nawet popadnięcia w płytki epigonizm, gdyż w tak wielu wypadkach lektura spostrzeżeń Profesora (zważywszy dodatkowo na rzadki Jego talent do ciętych i celnych sformułowań) nasuwa mało satysfakcjonującą ego konstatację, że niewiele na dany temat da się jeszcze sensownie dodać. Wybrniecie z opisanego kłopotu nie jest sprawą łatwą, lecz pewną szansę dostrzec można w ciągłej niestabilności, zmienności otaczającej nas rzeczywistości prawnej, zapewniającej — bez względu na nasz stosunek do zachodzących w niej procesów - wciąż nową perspektywę postrzegania problemów już omówionych, a przy okazji przyczyniającej się do powstania za każdym razem kilku kolejnych. W takich sytuacjach rozwiązania proponowane przez Jubilata, nawet te zawarte we wcześniejszych jego pracach $^{1}$, stają się wy-

* Tekst powstał w ramach badań sfinansowanych ze środków Narodowego Centrum Nauki przyznanych na podstawie umowy nr UMO-2015/19/D/HS5/00518.

1 Jak i - rzecz jasna - w pracach najnowszych, gdyż Profesor pozostaje cały czas aktywnym i niestrudzonym komentatorem otaczającej nas rzeczywistości prawnej. 
jątkowo argumentacyjnie użytecznym punktem odniesienia, co wydobywa ich kolejny, niewymieniony jeszcze walor — uniwersalność i niezmienną aktualność.

Jednym z najbardziej chyba charakterystycznych rysów obecnie obserwowanej ewolucji systemu prawa karnego staje się jego powolne, lecz i nieuchronne zmierzanie ku rozwiązaniom oraz instytucjom mającym genezę prywatno-, a nie publicznoprawną, dotąd całkowicie od siebie odseparowanym stosownie do założeń o wyraźnej dychotomii między tymi dwiema zasadniczymi gałęziami prawa ${ }^{2}$. We wrażliwszym na wszelkie zmiany społeczne lub po prostu zdatnym do szybszej na nie reakcji - choćby z racji podstawowego wymogu swej efektywności i kształtowania wedle założeń prakseologicznych — procesie karnym tendencje te wydają się szczególnie uchwytne, przybierając różne postacie wzmocnienia proceduralnych uprawnień oskarżonego oraz pokrzywdzonego, a niekiedy wręcz swoistej delegacji kompetencji w wymiarze sprawiedliwości karnej na te podmioty, usytuowane wszak poza tradycyjnym aparatem urzędniczym reprezentującym państwo jako niepodzielnego dotąd dzierżyciela prawa karania w imieniu całego społeczeństwa. Z drugiej strony to w prawie karnym materialnym szczególnie mocno dano wyraz potrzebom postrzegania należnej i sprawiedliwej reakcji na fakt popełnienia przestępstwa nie tylko w karze, lecz także w dotąd znamiennej co do perspektywy czysto cywilistycznej kompensacji ${ }^{3}$. Zestawienie z sobą tych dwóch kierunków zmian - prywatyzacji postępowania karnego redefiniującej podstawowe założenia co do zakresu i treści procesowych zasad legalizmu i oportunizmu oraz sprawiedliwości naprawczej w zakresie, w jakim włącza ona osobę i prawo ofiary do zaspokojenia doznanego uszczerbku w spór klasycznie prowadzony jedynie między sprawcą a społeczeństwem, a tym samym nie tylko oddziałuje na sferę konsekwencji tego sporu ${ }^{4}$, lecz także wkomponowuje interes

2 Jak stwierdza A von Hirsch, gdyby postrzegać prawo karne jako jeszcze jeden z regulatorów zachowań społecznych, wówczas nie ma zasadniczej różnicy miedzy nim a prawem cywilnym. Zarazem jednak autor zastrzega, że swoistość regulatora, jakim jest prawo karne, polega na jego społecznej i komunikacyjnej doniosłości związanej z karaniem. Prawo karne oddziałuje także na moralność adresatów swoich norm (,,przemawia moralnym głosem”, czego brakuje prawu cywilnemu. - A.P. Simester, A. von Hirsch, Crimes, Harms and Wrongs. On the Principles of Criminalisation, Oxford, Portland 2011, s. 4-5. Powyższe nie pozwala na zastąpienie instrumentów karnych wyłącznie instrumentami cywilistycznymi, równocześnie jednak nie stoi na przeszkodzie pewnym modyfikacjom owych instrumentów, w obszarach, w których mogą być one do siebie zbliżane.

3 Jak trafnie podsumowuje A. Muszyńska, wprowadzenie kompensacji oznaczało otwarcie drzwi dla „wzajemnego przenikania się zasad i pojęć prawa karnego i prawa cywilnego”. „Zestawienie elementu penalnego i kompensacyjnego oznaczało przełamanie utrwalonych schematów i skutkowało wprowadzeniem do prawa karnego konstrukcji normatywnych typowych dla dziedziny prawa cywilnego. Następujące w tym zakresie zbliżenie obu dziedzin prawa sprzyjało między innymi tworzeniu w prawie karnym swego rodzaju cywilnoprawnych środków reakcji karnej”, A. Muszyńska, Naprawienie szkody wyrządzonej przestęstwem, Warszawa 2010, s. 5.

${ }^{4}$ Czyli na sferę kar, innych środków reakcji prawnokarnej oraz ewentualnych poszukiwań sposobów wobec powyższych instrumentów alternatywnych, nawet jeżeli te ostatnie starania na- 
prywatny pokrzywdzonego w samą jego istotę ${ }^{5}, \mathrm{tj}$. statuując go obok dotąd rozstrzygającego interesu zbiorowości - rodzi intuicję, że nie mogą one pozostać bez znaczenia dla dotychczasowego spojrzenia na niektóre karnomaterialne dogmaty, w tym źródłowy problem ewaluacji zachowań, jakie w ogóle podlegać będą penalizacji, czyli innymi słowy wspomnianemu wcześniej sporowi. W tym kontekście i przy przyjęciu, że to właśnie społeczna szkodliwość wynikająca z postulatu ochrony dóbr prawnych, pozostaje tu — tak jak to zresztą wielokrotnie podkreślał Jubilat ${ }^{6}$ — kryterium zasadniczym, ponadto kryterium zespalającym kwestie materialnoprawne z proceduralnymi (właśnie od strony funkcjonowania zasady legalizmu ${ }^{7}$ ) powstaje zwłaszcza wątpliwość, na ile tendencje prywatyzacyjne wymiaru sprawiedliwości karnej znajdą odzwierciedlenie w ujmowaniu jej struktury.

Jakiekolwiek dalsze rozważania wymagają wstępnego odniesienia się do obu wymienionych zjawisk: sprawiedliwości restytucyjnej w prawie karnym i prywatyzacji prawa oraz procesu karnego, przy czym w stosunku do tej ostatniej konieczne jawi się również wyjaśnienie pewnych kwestii natury terminologicznej. Jak już wspomniano - w zmieniającym się otoczeniu kulturowym klasyczne struktury postępowania karnego wraz z charakterystycznym dla nich schematem relacji między państwem a podporządkowaną jednostką przestają odpowiadać społecznym oczekiwaniom co do reakcji procesowej na popełnione przestępstwo. Stawia to ustawodawców przed zadaniem poszukiwania nowych rozwiązań protrafiają na zarzut nadmiernie idealistycznego podejścia do funkcjonowania struktur społecznych. Por. J. Utrat-Milecki, Podstawy enologii. Teoria kary, Warszawa 2006, s. 253 n.

5 Por. C. Kulesza, Rola pokrzywdzonego w procesie karnym w świetle ustawodawstwa i praktyki wybranych krajów zachodnich, Białystok 1995, s. 29, który bezpośrednio wskazuje, że ograniczenia roli pokrzywdzonego w procesie wynikają wyłącznie z konfliktu między nim a interesami państwa i partykularnymi interesami jego przedstawicieli.

6 Poczynając od swoich najwcześniejszych prac: T. Kaczmarek, Społeczne niebezpieczeństwo czynu i jego bezprawność jako dwie cechy przestepstwa, Wrocław 1966; idem, Materialna istota przestępstwa i jego ustawowe znamiona, Wrocław 1968, czy współczesnych — idem, Dobro prawne i społeczna szkodliwość czynu, [w:] System Prawa Karnego, t. 3. Nauka o przestępstwie. Zasady odpowiedzialności, red. R. Dębski, Warszawa 2013, s. 278; idem, O elementach wyznaczajacych treść społecznej szkodliwości czynu zabronionego i jej stopień (ekspozycja problemów spornych), [w:] Teoretyczne i praktyczne problemy współczesnego prawa karnego. Księga jubileuszowa dedykowana Profesorowi Tadeuszowi Bojarskiemu, red. A. Michalska-Warias, I. Nowikowski, J. Piórkowska-Flieger, Lublin 2011, s. 133-134.

${ }^{7}$ Zasada legalizmu — jeszcze wedle podziału wprowadzonego przez A. Murzynowskiego ma charakter zasady materialnoprocesowej. Pozostaje ona wszak związana najściślej z funkcjami i celami prawa karnego materialnego. A. Murzynowski definiuje ją wręcz jako zasadę „ścigania zgodnego z dyrektywami prawa karnego materialnego", a to oznacza konieczność uwzględniania w jej ramach nie tylko zadań ochronnych, lecz coraz bardziej zyskującej na znaczeniu funkcji kompensacyjnej. A. Murzynowski, Istota i zasady procesu karnego, Warszawa 1976, s. 184. Jak zauważa C. Kulesza, zasada ta jest niewątpliwie refleksem w procedurze karnej samej istoty nowoczesnego prawa karnego, która nakazuje karać przestępców w imieniu społeczeństwa. Por. C. Kulesza, Rola pokrzywdzonego w procesie karnym w świetle zasady legalizmu ścigania, „Studia Iuridica" 33, 1997, s. 127. 
ceduralnych, co wyraża się w coraz większym zainteresowaniu zag adnieniami takimi, jak: kontradyktoryjność postępowania karnego, konsensualizm, uprawnienia oskarżonego do aktywnego wpływu na swoją sytuację procesową oraz przywrócenie ofierze przestępstwa jej roli pełnoprawnego podmiotu procesu. Także europeizacja prawa karnego (zarówno materialnego, jak i procesowego), będąc silnym źródłem idei humanitarnych i gwarancyjnych, ułatwia przenikanie z innych systemów prawnych zwłaszcza elementów odnoszących się do pozycji prawnej jednostek w procesie i standardów postępowania organów procesowych ${ }^{8}$. Równoczesnym i wypada dodać — równie silnym, o ile nawet nie najsilniejszym bodźcem jest zmniejszająca się efektywność klasycznego sprawowania sprawiedliwości w sprawach karnych — tym wyraźniejsza, im większe zagrożenia pociąga za sobą zmiana struktury przestępczości. Istotnym wyzwaniem staje się konieczność odciążenia tak organizacyjnego, jak i ekonomicznego służb i organów procesowych. Źródła koncepcji prywatyzacyjnych tkwią zatem w problemach, które dla współczesnego wymiaru sprawiedliwości stwarza nowoczesne społeczeństwo ryzyka, a które powstają na styku dążeń do wprowadzania wolnościowo zorientowanego modelu prawa i procesu karnego, wraz z postulatami dekryminalizacji i dejurydyzacji, a koniecznością zwiększenia skuteczności ochrony prawnokarnej (coraz częściej obecnej na dalekich granicach prewencji, co dodatkowo angażuje znaczne siły i środki) ${ }^{9}$. Znaczące, że są to jednocześnie te same trudności, przed którymi staje nauka o dobrach prawnych i społecznej szkodliwości, próbująca się jednak z nimi zmierzyć od strony kryteriów legitymacji ingerencji prawnokarnej. Samo zjawisko można natomiast definiować na dwa zasadnicze sposoby. Jeżeli na plan pierwszy wysunąć przekazywanie elementów prowadzenia postępowania podmiotom prywatnym, to obejmować ono będzie wskazywaną już erozję etatystyczno-inkwizycyjnego modelu procesu karnego, a zatem przenoszenie tradycyjnie zawarowanych dla organów państwowych, zwłaszcza organów ścigania i oskarżenia, zadań i funkcji procesowych na nieinstytucjonalnych uczestników postępowania (z czego zasadnicza rola w tak zmodyfikowanej procedurze przypada nie tylko oskarżonemu, lecz coraz aktywniej występującemu

8 Zob. interesujące uwagi G. Dannecker, Europäische Grundrechtsstandards bei der Verhängung repressiver Sanktionen: Verfahrensfairness und Beweisverbote im Recht der Europäische Union, [w:] Państwo prawa i prawo karne. Księa Jubileuszowa Profesora Andrzeja Zolla, red. P. Kardas, T. Sroka, W. Wróbel, Warszawa 2012, s. 185.

9 Por. J. Pipek, Offizieles oder weitgehend privatisiertes Strafverfahren, [w:] Zasady procesu karnego wobec wyzwań wspótczesności. Księga ku czci Profesora Stanisława Waltosia, red. J. Czapska et al., Warszawa 2000, s. 75; A. Eser, Funktionswandel strafrechtlicher Prozeßmaximen: Auf dem Weg zur „Reprivatisierung“ des Strafverfahrens?, ZStW (104) 1992, nr 2, s. 376-384; A. Dessecker, Privatisierung in der Strafrechtspflege: Einführung und Überblick, [w:] Privatisierung in der Strafrechtspflege, red. A. Dessecker, Wiesbaden 2008, s. 11 n. 
pokrzywdzonemu) ${ }^{10}$. W kontekście interesującej nas problematyki można też zauważyć, że takie zlecanie bywa często podyktowane poprawą efektywności sprawowania wymiaru sprawiedliwości w kwestiach stosunkowo mniej istotnych lub wpadkowych ${ }^{11}$, a zatem spełnia do pewnego stopnia analogiczną do materialnego warunku przestępstwa funkcję selekcyjną, choć nie tyle pozostawiając ewentualne czyny bagatelne w ogóle poza zakresem prawa karnego, ile jedynie poza zakresem postępowania karnego, przynajmniej w jego klasycznej formule. Można zatem w pewnym uproszczeniu powiedzieć, że wzbogaca dotychczas dostępny arsenał środków opartych albo na rozwiązaniach oportunistycznych, albo na wprowadzaniu określonego stopnia karygodności jako elementu struktury przestępstwa, o trzecią drogę w postaci delegacji kompetencji na podmioty prywatne ${ }^{12}$.

Drugi aspekt prywatyzacji to penetracja dotychczas homogenicznej konstrukcji publicznego prawa karnego przez instytucje o stricte cywilistycznej genezie. Tak też postrzega je M. Rogacka-Rzewnicka, proponując nawet równorzędne pojęcie „cywilizacji”13. Jak przyznaje, termin ten brzmi nieco prowokacyjnie ze

10 Zob. szerzej M. Burgi, Privatisierung öffentlicher Aufgaben - Gestaltungsmöglichkeiten, Grenzen, Regelungsbedarf. Gutachten für den 67. Deutschen Juristentag, [w:] Verhandlungen des Siebenundsechzigsten Deutschen Juristentages Erfurt 2008, t. 1, München 2008, s. D 9 n. Taka wizja przekształceń procesu w duchu właśnie prywatyzacji również nie jest do końca obca rodzimemu piśmiennictwu. Por. zwłaszcza A. Bojańczyk, Dowód prywatny w perspektywie prawnoporównawczej, Warszawa 2011; A. Ludwiczek, Pozaprocesowa działalność adwokata prowadzona w ramach tzw. „prywatnego gromadzenia dowodów”, [w:] Dowody w procesie karnym. Nowe rozwiazania i niewykorzystane możliwości, red. K. Marszał, Katowice 2005, s. 86, który wprost pisze o „,prywatyzacji« czynności dowodowych stron i ich przedstawicieli ustawowych".

11 Ciekawym przykładem właśnie takiego zjawiska jest choćby propozycja S. Waltosia, który jako kolejny krok rozwoju kontradyktoryjnej formy postępowania poddaje pod rozwagę zaadaptowanie do polskiego prawa karnego procesowego angielskiego systemu powierzania przez prokuraturę oskarżenia publicznego podmiotom zewnętrznym, mianowicie adwokatom i radcom prawnym, opisywany przez S. Waltoś, O rzeczniku oskarżenia publicznego - nieco inna koncepcja oskarżania publicznego na rozprawie, [w:] Fiat iustitia pereat mundus. Księga jubileuszowa poświęcona Sędziemu Sądu Najwyższego Stanisławowi Zabłockiemu z okazji 40-lecia pracy zawodowej, red. P. Hofmański, P. Kardas, P. Wiliński, Warszawa 2014.

12 Jak zatem widać, także w tym aspekcie uwidaczniają się związki między społeczną szkodliwością a prywatyzacją, tyle że w tym przypadku będzie to społeczna szkodliwość ujmowana już na płaszczyźnie stosowania prawa.

13 Zob. M. Rogacka-Rzewnicka, O zjawisku ,prywatyzacji” (,,cywilizacji”) prawa karnego $w$ świetle koncepcji celu postępowania karnego. Krótki rys historycznoprawny, Prok. i Pr. 2010, nr 1-2, s. 235 i cytowana tam liczna literatura francuskojęzyczna. Termin „prywatyzacja” wydaje się jednak o tyle językowo użyteczniejszy (chciałoby się powiedzieć - szczęśliwszy), że nie rodzi skojarzeń z nabywaniem przez prawo karne cech prawa cywilizowanego zamiast cywilnego. W cudzysłowie terminu ,prywatyzacja” w odniesieniu do prywatnego gromadzenia dowodów używał też A. Ludwiczek, Pozaprocesowa działalność adwokata prowadzona w ramach tzw. "prywatnego gromadzenia dowodów «, [w:] Dowody w procesie karnym. Nowe rozwiąania i niewykorzystane możliwości, red. M. Nowak, M. Golec, Katowice 2005, s. 86, zob. też ostatnio A.H. Ochnio, Kilka refleksji na temat prywatnego gromadzenia dowodów w procesie karnym, [w:] Pozaprocesowe pozyskiwanie dowodów i ich wykorzystanie w procesie karnym. Ausserprozessuale Beweiserhebung 
względu na prima facie wykluczające się i przez długie lata negowane zbliżenie między tak systemowo obcymi sobie konstrukcjami i środkami, jakimi dysponuje prawo publiczne i prawo cywilne (prawo prywatne). Jednak zarówno wzrost znaczenia funkcji kompensacyjnej prawa karnego, jak i ukierunkowanie postępowania karnego ku charakterystycznym dla prawa cywilnego formom rozwiązywania konfliktów, jak mediacja czy ugoda, również porozumienia procesowe i tym samym ograniczenie jego oficjalności oraz uczynienie z realizacji prywatnych interesów pokrzywdzonego jednego z celów tego postępowania uprawniają do upatrywania właśnie w naturze prawa cywilnego wspólnego mianownika tych zmian. Rzecz jasna proces ten nie wpływa na samą systemową przynależność prawa karnego, lecz jedynie „ułatwia znalezienie w argumentacji, akcentującej nową rolę procesu karnego, uzasadnienia dla ewolucji współczesnego prawa karnego w kierunku ucywilnienia jego założeń i procedur"14. Nawiązując do poglądów J. Benthama, M. Rogacka-Rzewnicka celnie też dalej argumentuje, że wzajemne współistnienie materii karnej i cywilnej w regulacjach formalnie wydzielonych w osobne reżimy wynika z niepodzielności materiału jurydycznego, a tym samym poniekąd z niepodzielności systemu prawnego ${ }^{15}$.

Ideologiczne zaplecze powyższego przewartościowania w prawie karnym stanowi przede wszystkim nurt sprawiedliwości naprawczej ${ }^{16}$ wraz ze wszystkimi swymi konsekwencjami dla współczesnej percepcji roli ofiary i sprawcy oraz osobistego ${ }^{17}$ wymiaru ich sporu. Prawo karne, zwracając się ku pokrzywdzonemu, uznało za równoważną składową sprawiedliwej reakcji na czyn zabroniony nie tylko zapewnienie przez państwo w ramach przysługującego mu ius puniendi

und ihre Verwertung im Strafprozess, red. P. Hofmański, D. Szumiło-Kulczycka, P. Czarnecki, Warszawa 2015, s. 321.

14 M. Rogacka-Rzewnicka, op. cit., s. 236.

15 Ibidem, s. 238.

16 Nie ma pewności, kto pierwszy posłużył się pojęciem sprawiedliwości naprawczej. Autorstwo terminu przypisywane jest Albertowi Eglashowi i wiązane z jego artykułem z 1977 r. Beyond Restitution: Creative Restitution, jak również Randy’emu Barnettowi, który w tym samym roku przedstawił swoje założenia reformy wymiaru sprawiedliwości w eseju: Restitution: A New Paradigm of Criminal Justice. Niemniej po raz pierwszy program sprawiedliwości naprawczej w sposób całościowy zaprezentowany został przez Howarda Zehra w opublikowanym w 1985 r. eseju: Retributive Justice, Restorative Justice oraz późniejszej pracy Changing Lenses: A New Focus for Crime and Justice, wydanej w 1990 r. Por. J. Różyńska, Koncepcja sprawiedliwości naprawczej, „Jurysta” 2005, nr 1, s. 6; szerzej o nurcie sprawiedliwości naprawczej: M. Wright, Geneza i rozwój sprawiedliwości, [w:] idem, Przywracając szacunek sprawiedliwości, przeł. M. Marcinkowska, Warszawa 2005; W. Zalewski, Sprawiedliwość naprawcza. Poczatek ewolucji polskiego prawa karnego?, Gdańsk 2006; J. Consedine, Sprawiedliwość naprawcza. Przywrócenie ładu społecznego, przeł. M. Wołodźko, K. Gradoń, Warszawa 2004; Handbook of Restorative Justice, red. G. Johnstone, D.W. Van Ness, Cullompton 2007; Restorative Justice and Criminal Justice, red. A von Hirsch et al., Oxford 2003.

17 Ewentualnie wymiaru społecznego (choć też w rozumieniu społeczności lokalnej, raczej nie społeczeństwa jako ogółu), lecz już nie państwowego. 
ukarania sprawcy, lecz także naprawienie szkody wyrządzonej drugiemu członkowi społeczeństwa ${ }^{18}$. Wyodrębnienie zatem nowej funkcji prawa karnego, jaką stała się funkcja kompensacyjna, uwarunkowane było dojściem do głosu — na tle kryzysu tradycyjnego systemu wymiaru sprawiedliwości karnej — poglądów akcentujących z jednej strony konieczność zabezpieczenia interesów i potrzeb ofiary przestępstwa, jak również przywrócenia jej szerszych możliwości działania w procesie ustalania i wymierzania sankcji karnej, oraz — z drugiej strony — oferując i sprawcy nowe środki zadośćuczynienia wyrządzonemu złu, również w drodze porozumień, mediacji, i dobrowolnego przyjęcia na siebie odpowiedzialności. Choć obecnie zwraca się uwagę na konieczność współistnienia obok sprawiedliwości państwowej form sprawiedliwości restytuującej, oferując różne sposoby syntezy owych dwóch modeli ${ }^{19}$, sprawiedliwość naprawcza w swej genezie stanowiła i nadal stanowi nurt opozycyjny względem sprawiedliwości retrybucyjnej oraz jej tradycyjnych form ,upaństwowienia” konfliktu między sprawcą a ofiarą. Postulowała ona też zmianę paradygmatu postrzegania istoty przestępstwa - jako zachowania naruszającego normę sankcjonowaną, czyli wyrażoną w zakazie karnym wolę prawodawcy, a tym samym wolę zbiorowości i państwa, ku wysunięciu na plan pierwszy elementów indywidualnej straty podmiotu poszkodowanego ${ }^{20}$.

18 Zob. obszerne uwagi A. Muszyńskiej, op. cit., s. 42 n.; M. Królikowski, Sprawiedliwość karania w społeczeństwach liberalnych. Zasada proporcjonalności, Warszawa 2005; J. Skorupka, Wybrane zagadnienia z problematyki funkcji kompensacyjnej prawa karnego, [w:] Karnomaterialne i procesowe aspekty naprawienia szkody, red. Z. Ćwiąkalski, G. Artymiak, Warszawa 2010, s. 43; E. Bieńkowska, Funkcja kompensacyjna polskiego prawa karnego, „Iuris Effectus. Kwartalnik Krajowej Szkoły Sądownictwa i Prokuratury", z. spec. — Ofiary przestepstw. Seminarium z okazji Dnia Ofiar Przestepstw nt. „Naprawienie szkody pokrzywdzonemu”, Warszawa 23 II 2009, s. 6 n.; interesująco analizując poglądy M. Cieślaka - W. Zalewski, R. Skarbek, Funkcja kompensacyjna prawa karnego oraz wybrane zagadnienia egzekucji roszczeń w postępowaniu karnym, [w:] Profesor Marian Cieślak - osoba, dzieło, kontynuacje, red. W. Cieślak, S. Steinborn, Warszawa 2013, s. 545 n.

19 H. Zehr, The Little Book of Restorative Justice, Pennsylvania 2002, s. 58; M. Płatek, Teoria sprawiedliwości naprawczej, [w:] Sprawiedliwość naprawcza. Idea. Teoria. Praktyka, red. M. Płatek, M. Fajsta, Warszawa 2005, s. 76-77; W. Zalewski, Przeciw mediacji w prawie karnym czyli o rzeczywistych i urojonych granicach mediacji, [w:] Reforma prawa karnego, propozycje i komentarze. Ksiegga pamiatkowa Profesor Barbary Kunickiej-Michalskiej, red. J. Jakubowska-Hara, C. Nowak, J. Skupiński, Warszawa 2008, i cyt. tam literatura; B.D. Meier, op. cit., s. 46.

20 Jat trafnie zauważa M. Płatek, analizując teoretyczne podstawy sprawiedliwości naprawczej, „sprawiedliwość naprawcza rozumie przestępstwo przede wszystkim jako krzywdę, stratę, uszczerbek jaki poniósł pokrzywdzony, a nie jako złamanie ustawy karnej [...] sprawiedliwość w ujęciu sprawiedliwości naprawczej wymaga i bierze swój początek w dostrzeżeniu ofiary i uwzględnieniu jej potrzeb". M Płatek, op. cit., s. 77; D.W. van Ness, K.H. Strong podkreślają, że sprawiedliwość naprawcza skupia się właśnie na szkodzie wywołanej przestępstwem i redukcji prawdopodobieństwa dalszych szkód. D.W. Van Ness, K.H. Strong, Restoring Justice, Cincinnati 1997, s. 58. Szczególnie interesujące wydają się natomiast na tym tle uwagi M. Królikowskiego, wiążącego wizję przestępstwa nurtu restorative justice i uprawnienia pokrzywdzonego z niej wynikające z karnomaterialną instytucją zgody dysponenta dobrem prawnym — por. M. Królikow- 
Stosownie do poglądów zwolenników nurtu sprawiedliwości naprawczej w przestępstwie uwidacznia się przede wszystkim indywidualistycznie odbierane pokrzywdzenie, zaburzenie relacji między krzywdzącym a jego ofiarą, dopiero zaś $\mathrm{w}$ dalszej kolejności element wystąpienia przeciwko prawu i państwu ${ }^{21}$. W powyższej koncepcji fakt popełnienia czynu zabronionego implikuje zaangażowanie trzech podmiotów: sprawcy, ofiary i (ewentualnie) wspólnoty, lecz już nie państwa czy tworzącego państwo społeczeństwa ${ }^{22}$. „Przestępstwo jest naruszeniem osób i związków miedzy nimi. Tworzy zobowiązanie do przywrócenia porządku"23. Przestępstwo staje się tym samym czynem przeciwko jednostce, wkroczeniem $\mathrm{w}$ jej sferę praw podmiotowych. Tym samym dochodzić ma do przywrócenia pokrzywdzonemu jego konfliktu i roszczenia wynikającego z pokrzywdzenia przestępstwem, z którego - cytując N. Christiego - został on „okradziony przez państwo"24. Jak podkreśla B.D. Meier — koncepcja sprawiedliwości naprawczej przeciwstawia się wyraźnie klasycznej wizji przestępstwa i kary, opartym na przekonaniu o „wyrównawczej” funkcji sankcji państwowej, czyli przekonaniu, że krzywda wyrządzona jednostce powinna być wyrównana karą wymierzoną przez państwo ${ }^{25}$. M.S. Umbreit wskazuje natomiast, że podstawowa zasada sprawiedli-

ski, Wokót problematyki tzw. umorzenia restytucyjnego, [w:] Problemy wymiaru sprawiedliwości. Księga Jubileuszowa Profesora Jana Skupińskiego, red. A. Błachnio-Parzych et al., Warszawa 2013, s. 75.

21 J. Różańska, Koncepcja sprawiedliwości naprawczej, „Jurysta” 2005, nr 1, s. 7; D. Wójcik [w:] System Prawa Karnego, t. 1. Zagadnienia ogólne, red. A. Marek, Warszawa 2010, s. 351.

22 Należy jednak zaznaczyć, że z uwagi na niejednolitość nurtów sprawiedliwości naprawczej proporcje między tymi trzema podmiotowymi składowymi bywają postrzegane różnie, niekiedy całkowicie z marginalizując element udziału społeczności — por. C. Domenig, Restorative Justice. Vom marginalne Verfahrensmodell zum integralen Lebensentwurf, [w:] Restorative Justice - der Versuch, das Unübersetzbare in Worte zu fassen. DBH-Materialen, Fachverband für Soziale Arbeit, Strafrecht und Kriminalpolitik, Köln 2013, s. 12 n.

${ }^{23}$ H. Zehr, Changing Lenses: A New Focus for Crime and Justice, Scottsdale 1990, s. 181, za: W. Zalewski, Naprawienie szkody w polskim procesie karnym a postulaty restorativ justice, [w:] Kompensacyjna funkcja prawa karnego. Księga poświęcona pamięci Profesora Zbigniewa Gostyńskiego, red. S. Waltoś et al., Kraków 2002, s. 78-79. Należy jednak zaznaczyć, że ze względu na niejednolitość nurtów sprawiedliwości naprawczej proporcje pomiędzy tymi trzema podmiotowymi składowymi bywają postrzegane różnie, tj. z większym lub zupełnie marginalizowanym udziałem społeczności por. C. Domenig, op. cit., s. 12 n.

24 N. Christie, Conflicts as property, „British Journal of Criminology” 1977, nr 17, zob. także idem, Granice cierpienia, przeł. L. Falandysz, Warszawa 1991.

25 B.D. Meier, Sprawiedliwość naprawcza - zarys koncepcji, [w:] Mediacja. Nieletni przestępcy $i$ ich ofiary, red. B. Czarnecka-Dzialuk, D. Wójcik, Warszawa 1999, s. 40. Zwolennicy nurtu sprawiedliwości naprawczej słusznie wskazują, że w toku rozwoju historycznego nowożytne oświeceniowe państwo, rozdzielając sferę prawa prywatnego od publicznego, przejęło uprawnienia ofiary przestępstwa, zastępując dotychczasową sprawiedliwość restytucyjną sprawiedliwością państwową. Tym samym w miejsce dotychczasowej ofiary wprowadzono państwo, które zajęło jej miejsce w relacji sprawca-ofiara i ono też rozliczało za czyn skierowany przeciwko ustalonemu porządkowi prawnemu. Zob. szerzej W. Zalewski, Historyczne przekształcenia idei kompensacji 
wości naprawczej wymaga fundamentalnego przesunięcia władzy kontrolowania i decydowania o przestępstwach w społeczeństwie ${ }^{26}$. Wiąże się ją także z porzuceniem idei swoistego, przysługującego państwu wskutek popełnienia czynu zabronionego roszczenia karnego (Staatsstrafanspruch) ${ }^{27}$ lub też w dalekiej modyfikacji istoty takiego roszczenia w modelu, który zakłada wkomponowanie sprawiedliwości naprawczej w upaństwowiony wymiar sprawiedliwości ${ }^{28}$.

Bez względu jednak na to, czy skoncentrujemy się w pierwszej kolejności na przenikaniu instytucji cywilnoprawnych do prawa materialnego, czy też odpowiadających im modyfikacjach procedury karnej, jeden element wspólny tym przemianom nie może nie zwrócić naszej uwagi - mianowicie wzmocnienie roli interesu prywatnego w procesie oceny zasadności ingerencji karnej i kwalifikacji zachowań jako szkodliwych w stopniu tę ingerencję, mimo limitującego oddziaływania zasady ultima ratio, usprawiedliwiającym. Przy zastrzeżeniu, że osią takiej ewaluacji jest kategoria społecznej szkodliwości ${ }^{29}$, to właśnie w niej nastąpić

w ramach odpowiedzialności karnej, Pal. 2002, nr 3-4; L. Mazowiecka, Państwowa kompensata dla ofiar przestępstw, Warszawa 2012, s. 30 n.; D. Szumiło-Kulczycka, Proces karny a idea sprawiedliwości naprawczej, [w:] System Prawa Karnego Procesowego. Zagadnienia ogólne, I cz., red. P. Hofmański, Warszawa 2013, s. 369-377; M. Królikowski, Sprawiedliwość retrybutywna wobec sprawiedliwości naprawczej, „Ius et Lex” 2006, nr 1, s. 113 n.

26 M.S. Umbreit, Victim Meets Offender: The Impact of Restorative Justice and Mediation, Monsey, NY 1994, s. 164. W innej swej pracy autor podkreśla, że: „Zamiast postrzegania państwa jako pierwszej i głównej ofiary działania przestępnego i umieszczaniu ofiar, sprawców oraz wspólnoty w rolach biernych, sprawiedliwość naprawcza uznaje przestępstwo za czyn skierowany ku konkretnym ludziom". M.S Umbreit, Restorative Justice in the Twenty-first Century: A Social Movement full of Opportunities and Pitfalls, „Marquette Law Review” 2005, nr 89 (2), s. 255 http:// www.cehd.umn.edu/ssw/rjp/resources/rj_dialogue_resources/RJ_Principles, tak. też w M.S. Umbreit, M. Peterson Armour, Restorative Justice Dialogue, New York 2011, s. 4-5.

27 Zob. A. Marek [w:] System Prawa Karnego, t. 1, s. 19; idem, Naprawienie szkody wyrzadzonej przestępstwem. (Refleksje na tle projektu nowej kodyfikacji karnej), [w:] Problemy kodyfikacji prawa karnego. Księga ku czci Profesora Mariana Cieślaka, red. S. Waltoś, Kraków 1993, s. $205 \mathrm{n}$.

28 J. Shapland [w:] Restorative Justice..., red. A. von Hirsch et al., s. 203 - autorka wyróżnia dwa modele funkcjonowania sprawiedliwości naprawczej jako część wymiaru sprawiedliwości karnej lub — poza jego granicami — jako całkowicie alternatywny system.

29 Nie wydaje się przy tym, by wspomniane funkcje społecznej szkodliwości mogła w całości, i to zapewniając lepszą ich realizację, przejąc sama zasada proporcjonalności - M. Dąbrowska-Kardas, O dwóch znaczeniach pojęcia społecznego niebezpieczeństwa czynu, CZPKiNP 1997, z. 1, s. 29-30. Jej sens sprowadza się do rozstrzygnięcia kolizji między zasługującymi na ochronę wartościami. Zasada społecznej szkodliwości w jej współczesnym rozumieniu opartym na paradygmacie ochrony dóbr prawnych poprzez skupienie się na centralnym swym elemencie, którym jest właśnie owo dobro prawne, odpowiada jednak na wcześniejsze pytanie, co w ogóle może być taką chronioną przez prawo karne wartością. Dlatego zasadne są zastrzeżenia T. Kaczmarka, że przede wszystkim trzeba rozstrzygnąć, jaka właściwość ludzkiego zachowania sprawia, że spośród wszystkich możliwych czynów tylko niektóre z nich są przez prawo zakazane lub nakazane, a zatem co stanowi ratio essendi ich bezprawności oraz karalności, a dopiero później stosować inne kryteria jak np. zasada ultima ratio. T. Kaczmarek, Dobro prawne..., s. 277-278. 
musi manifestacja tej personalistycznej, a nie przede wszystkim ogólnospołecznej perspektywy, albowiem aprobując w pełni twierdzenie, że społeczna szkodliwość stanowi wyznacznik istoty prawa karnego ${ }^{30}$, nie trudno wskazać jak silnie, wręcz pierwotnie, pozostaje ona związana przede wszystkim właśnie z problemem oficjalności przestępstwa lub też nadawania mu wymiaru bardziej prywatnego. Jak zauważa, powołując się jeszcze na poglądy W. Woltera, R. Zawłocki -

Konstrukcja karnoprawna w postaci „społecznej szkodliwości czynu” niewątpliwie oddaje określony pogląd na istotę prawa karnego, którą można przecież pojmować na różne sposoby. Odnosząc się tutaj jedynie do skrajnych poglądów, należałoby wskazać na oparcie reakcji karnoprawnej na indywidualnym pokrzywdzeniu (szkodzie osoby pokrzywdzonej) oraz na naruszeniu bezwzględnych (,ponadspołecznych”) wartości (np. religijnych lub moralnych. [...] Wprowadzenie i zachowanie „społecznej szkodliwości” czynu w prawie karnym ściśle determinuje jego istotę, a w konsekwencji jego interpretację i związane z nim praktyczne stosowanie regulacji prawnokarnych. W każdym razie ewentualna eliminacja tej konstrukcji nie byłaby obojętna dla obowiązującej definicji prawa karnego, ma ona bowiem ściśle określony aksjologiczny charakter, dlatego wymagałoby to również pogłębionego aksjologicznego uzasadnienia. Należy też zauważyć, że pozbycie się omawianej konstrukcji doprowadziłoby do sytuacji, w której każda z wyżej wskazanych skrajnych wizji prawa karnego byłaby uprawniona, co rodziłoby zasadniczy spór na temat istoty współczesnego prawa karnego ${ }^{31}$.

Zastrzec już tu trzeba, że nie chodzi jedynie o zwykłe zmiany kulturowe czy polityczne, od których społeczna szkodliwości pozostaje wszak w naturalny sposób uzależniona, ponieważ jej istota wyraża się właśnie we wrażliwości na system wartości akceptowany przez daną wspólnotę w danym czasie, lecz których odziaływanie na samą jej strukturę, na elementy ją kształtujące, jest powierzchowne ${ }^{32}$. Intuicyjnie można przyjąć, że mamy do czynienia ze zmianą systemową nakazującą weryfikację właśnie tej wewnętrznej struktury społecznej szkodliwości co najmniej w postaci rozważania przesunięcia punktu ciężkości wartościowania ku szkodzie ujmowanej czysto indywidualistycznie, a następnie spojrzenia na nowo na kategorie ją tworzące. Innymi słowy można ująć tę różnicę jako kwestię nie zmiany wartościowania danych zjawisk pod kątem ich społecznej szkodliwości, lecz zmiany kryteriów społecznej szkodliwości jako samego instrumentu wartościowania. Prowokuje to oczywiście pytanie, jak daleko będziemy w stanie się posunąć i czy taka społeczna szkodliwości nie zatraci swojego pierwszego członu, właśnie w postaci bycia „społeczną”? Można zauważyć, że jakkolwiek poważne byłyby inkluzje cywilistyczne w gałąź prawa karnego, to mogą one jedynie spowodować pewne przesunięcia akcentów w treści społecznej szkodliwości, nie

30 R. Zawłocki, Pojęcie i funkcje społecznej szkodliwości w prawi karnym, Warszawa 2007, s. $131 \mathrm{n}$.

31 Ibidem, s. 131-132.

32 Przykładowo - zmiany w społecznym podejściu do kwestii płci i zwiększenie tolerancji odmiennych praktyk seksualnych oznaczają cofnięcie społecznego przyzwolenia na kryminalizację zachowań homoseksualnych, co zmienia tylko efekt oceny, a nie sam sposób oceny. 
przekreślą zaś samej potrzeby uzależnienia decyzji ustawodawcy od powszechnej zgody na zastosowanie represji karnej jako ostatecznego środka regulacji zachowań, możliwej do uzyskania tylko w wypadku ogólnego lub przynajmniej przeważającego potępienia materii zyskującej na tej, a nie jakiejkolwiek innej, drodze przymiot szkodliwości, czyli tego co stanowi najgłębszy gwarancyjny sens zasady nullum crimen sine pericculo sociali. Zastrzeżenie to jawi się jako konieczne, by z góry przekreślić również wszelkie wątpliwości co do wprowadzania interesu prywatnego $\mathrm{w}$ tym rozumieniu, w jakim mógłby on być mylony $\mathrm{z}$ tendencjami antyliberalnymi i antydemokratycznymi, przekazującymi jednostce lub mniejszości prawo decydowania za ogół i bez liczenia się ze zdaniem czy interesem ogółu, szczególnie złowrogimi w obszarze władzy karania. Powracając do cytowanych już wcześniej uwag R. Zawłockiego, należy zgodzić się, że społeczna szkodliwość chroni nas też przed skrajnością, jaką byłoby sprowadzenie przestępstwa wyłącznie do prywatnego konfliktu, pozbawionego jakiegokolwiek wymiaru ogólniejszego i tym samym społecznej doniosłości ${ }^{33}$. Już choćby dlatego sam byt tej kategorii wydaje się niezagrożony. W tym też sensie można bronić tezy, że nie stanowi ona kompromisu pomiędzy przeciwstawnymi kierunkami w ujmowaniu przestępstwa. Zatem szkodliwość, nawet jeżeli postrzegana w większym niż dotychczas stopniu przez pryzmat szkody/krzywdy indywidualnej, pozostanie odwzorowująca aprobatę zbiorowości dla samej procedury, jak i efektu ewaluacji danego zachowania. Inną jednak sprawą jest to, czy poszczególne kryteria, które kształtują tę ocenę w odniesieniu do płaszczyzny kryminalizacji, będą mogły także ostać się zorientowane jedynie na wymiar ogólnospołeczny.

Szeroko analizując fenomen społecznej szkodliwości i społecznego niebezpieczeństwa, jeszcze w latach 60 . T. Kaczmarek wyodrębnił trzy tego rodzaju kryteria i podział ten właściwie po dziś dzień trudno by było podważyć. Przy uznaniu, że „za przestępstwo można uważać tylko takie czyny społecznie niebezpieczne, które przedstawiają znaczne prawdopodobieństwo naruszenia określonych interesów, odpowiadają aktualnym stosunkom społecznym i które zarówno w sensie obiektywnym, jak i subiektywnym mogą być celowo zwalczane za

33 „Społeczna szkodliwość” czynu jest właśnie wyrazem takiego ujęcia karnoprawnej reakcji (ratio legis generali regulacji prawnokarnych), jednocześnie nie stanowi ona swoistego wypośrodkowania (łącznika) wskazanych dwóch skrajnych tendencji, albowiem z jednej strony odrzuca indywidualną szkodę jako podstawę reakcji karnoprawnej, wskazując na konieczność ogólnospołecznej oceny pojedynczego aktu krzywdy, z drugiej zaś uprawnia do rozważań naruszenia określonych wartości i związanych z nimi ludzkich przekonań tylko wtedy, gdy mają one odzwierciedlenie w rzeczywistych stosunkach społecznych, czyli wtedy, gdy są one przekonaniami (wartościami) o charakterze ogólnospołecznym, a nie tylko określonej grupy społecznej, a tym bardziej — pokrzywdzonego. W powyższym kontekście omawiana konstrukcja oddala istotę prawa karnego od jej ujęcia naturalnoprawnego czy sprowadzającego prawo karne do relacji (konfliktu) pomiędzy sprawcą a pokrzywdzonym. R. Zawłocki, op. cit., s. 131. 
pomocą kary" "34, przedstawiają się one następująco: kryterium znacznego prawdopodobieństwa naruszenia określonych interesów, wartościowania szkodliwych następstw pod kątem określonej wagi i stopnia interesów chronionych przez prawo karne oraz celowości zwalczania czynów społecznie szkodliwych za pomocą kary ${ }^{35}$. Bez większych trudności da się niewątpliwie wykazać oddziaływanie procesów prywatyzacyjnych - przede wszystkim na trzeci z wymienionych elementów. Jak dalej wyjaśnia jego znaczenie T. Kaczmarek — ocena społecznej szkodliwości wiąże się tu z czynnikiem celowości, albowiem im wachlarz skutecznych środków jest szerszy, tym zmniejsza się prawdopodobieństwo sięgnięcia przez prawodawcę do środków karnorepresyjnych. Pomiędzy celowością karania a społeczną szkodliwością zachodzi dwojakiego rodzaju sprzężenie - z jednej strony kara może być wywołana jedynie faktem wystąpienia społecznej szkodliwości, z drugiej - o tym, czy czyny społecznie szkodliwe podlegać będą karze, decydują cechy tej ostatniej. „Aby uznać określony rodzaj społecznie niebezpiecznych czynów przez ustawodawcę za przestępne, konieczna jest ocena, że kara zarówno stosowana w poszczególnym przypadku, jak i represja karna w całokształcie jej działania są skutecznymi środkami do ich celowego zwalczania"36. Przy jednym z podstawowych postulatów nurtów sprawiedliwości naprawczej, jakim jest - co celnie ujął N. Christie — nie tyle poszukiwanie kar alternatywnych, ile skoncentrowanie się na alternatywach kar $^{37}$, uznanie skuteczności kary podlegać musi ograniczeniu do bezwzględnej konieczności. Rzecz jasna można by od razu zastrzec, że przecież akceptacja założeń liberalnego prawa karnego, opartego na regule jego subsydiarności, również implikuje podobne zawężenie. Kara, która nie jest konieczna, także $\mathrm{w}$ tradycyjnym układzie relacji między prawem karnym a innymi gałęziami prawa nie znajdzie uzasadnienia. Rzecz jednak w tym, że w przypadku tendencji prywatyzacyjnych na konieczność kary wpływ ma osobisty sąd podmiotu naruszonych dóbr prawnych. Ustawodawca zatem z góry zakłada możliwość wystąpienia konfliktu pomiędzy koniecznością kary, ocenianą wyłącznie z perspektywy ogólnospołecznej - jako jedynego skutecznego środka zapewniającego przywrócenie porządku prawnego i powszechnego poczucia praworządności, wypełniającego funkcje ogólnoprewencyjne, lecz także oddziałującego w pożądany przez zbiorowość sposób na sprawcę, a czysto indywidualistycznie postrzeganym interesem pokrzywdzonego w doborze rodzaju konsekwencji wiążących się z czynem sprawcy ${ }^{38}$. Kara może być zatem jak najbardziej

34 T. Kaczmarek, Społeczne niebezpieczeństwo czynu i jego bezprawność jako dwie cechy przestepstwa, „Acta Universitatis Wratislaviensis. Prawo” 16, 1966, nr 49, [w:] idem, Rozważania o przestępstwie i karze. Wybór prac z okresu 40-lecia naukowej twórczości, Warszawa 2006, s. 72.

35 T. Kaczmarek, Społeczne niebezpieczeństwo..., s. 66.

${ }^{36}$ Ibidem, s. 72.

37 N. Christie, Granice cierpienia.

38 Na tego rodzaju konflikcie oparta była wprowadzona ustawą nowelizacyjną z 27 września 2013 r. nowatorska instytucja tzw. umorzenia restytucyjnego z art. 59a k.k. (por. m.in. M. Królikowski, 
celowa i usprawiedliwiona zadaniami, jakie tradycyjnie ma do wypełnienia $\mathrm{w}$ interesie społeczeństwa, lecz przestać być celowa, gdy tylko byłoby to sprzeczne z przekonaniem pokrzywdzonego o jej zasadności, a konkretnie o jej zdatności do wyrównania lub złagodzenia krzywdy, która została mu wyrządzona. Warto od razu zastrzec, że taka ewentualna różnica w postrzeganiu celowości kary sięga w analizowanych przypadkach dużo głębiej niż tylko przy rozstrzyganiu pierwszeństwa kompensacji nad represją w drodze już istniejących rozwiązań, wkomponowujących się przykładowo w środki probacyjne czy konstrukcje czynnego żalu lub też — od strony formalnoprawnej — w ewentualne rozstrzygnięcie o niecelowości ścigania przy wyjątkach oportunistycznych, i ma też z tego względu bardziej znaczące następstwa, albowiem w przeciwieństwie do wspomnianych instytucji nie aktualizuje się już po ostatecznym i niepodważalnym poza ścieżką legislacyjną zaszeregowaniu przez ustawodawcę danej kategorii czynów do klasy przestępstw - wszak rozstrzygnięcie o niecelowości karania w razie naprawienia przez sprawcę szkody nie zmienia ani niczego w postrzeganiu jego postępowania jako przestępstwa, ani też tym bardziej w szacowaniu społecznej szkodliwości czynów, których wzorzec ujęty został w naruszonej przez sprawcę normie sankcjonowanej $^{39}$, lecz raczej na etapie kwalifikacji zachowań. Nie oddziałuje zatem dopiero na płaszczyźnie indywidualno-konkretnego wartościowania, co przekreślałoby zasadniczo potrzebę jej rozważania w kontekście interesującej nas problematyki, lecz już na poziomie abstrakcyjno-generalnym, pozostając w ścisłym związku ze społeczną szkodliwością jako podstawą kryminalizacji. W literaturze wysunięto sugestie, że w ten sposób może dochodzić do wykreowania nowej kategorii przestępstw, najbardziej zbliżonych do przestępstw wnioskowych ${ }^{40}$. Pew-

Wokót problematyki..., s. 69; A. Lach, Umorzenie postępowania karnego na podstawie art. 59a k.k., Prok. i Pr. 2015, nr 1-2, s. 137; M. Kurowski, Umorzenie postepowania na podstawie art. 59 a K.K., [w:] Polski proces karny i materialne prawo karne w świetle nowelizacji z 2013 roku. Księga jubileuszowa dedykowana Profesorowi Januszowi Tylmanowi z okazji Jego 90. urodzin, red. T. Grzegorczyk et al., Warszawa 2014, s. 450), zlikwidowanego jednak wraz z wycofaniem się obecnego prawodawcy z założeń przemodelowania polskiego procesu karnego w kierunku zwiększenia jego kontradyktoryjności. W piśmiennictwie wiele uwagi poświęcono zwłaszcza charakterowi tej instytucji i jej ratio legis, zawierającym się w niecelowości prowadzenia procesu karnego oraz karania w sytuacji naprawienia przez sprawcę szkody — por. M. Rogacka-Rzewnicka [w:] System Prawa Karnego Procesowego, t. 3. Zasady procesu karnego, cz. 1, red. P. Wiliński, Warszawa 2014, s. 532; Ł. Chojniak, Umorzenie restytucyjne — odpowiedź na zjawisko nadmiernej kryminalizacji i penalizacji?, [w:] Granice kryminalizacji i penalizacji, red. S. Pikulski, M. Romańczuk-Grądzka, Olsztyn 2013, s. 309; zob. też przegląd stanowisk i argumentację za materialnoprawnym charakterem - B.J. Stefańska, Umorzenie kompensacyjne: instytucja karnomaterialna czy procesowa, [w:] Konsensualizm i kompensacja a podstawy odpowiedzialności karnej, red. I. Sepioło-Jankowska, Warszawa 2016, s. 365-366.

39 Choć oczywiście zmienia stopień społecznej szkodliwości ujmowanej jako karygodność, lecz to zupełnie inne zagadnienie.

40 Właśnie w ten sposób - jako mechanizmu postawania nowego rodzaju przestępstw podobnych konstrukcyjnie do przestępstw wnioskowych — niektórzy autorzy tłumaczyli istotę regulacji uchylonego art. 59a k.k.; zob. A. Lach, op. cit., s. 138. 
ne podobieństwo nasuwa się także w odniesieniu do przestępstw prywatnoskargowych $^{41}$. Gdyby zatem chcieć, choćby przez analogię, odnieść do zagadnienia społecznej szkodliwości tych ostatnich, można zauważyć, że w doktrynie chyba nieco pospiesznie przyjmuje się, że niczym one się nie różnią w tym względzie od przestępstw ściąganych z oskarżenia publicznego ${ }^{42}$. Procesualiści już dawno rozstrzygnęli, że tryb ścigania przestępstw pozostawać ma kwestią wewnętrzną tej dziedziny prawa, w żadnym razie nieuwikłaną karnomaterialne. W. Daszkiewicz, odnosząc się do istoty skargi prywatnej, zauważał, że

Skarga prywatna, tak samo jak publiczna, jest aktem procesowym. Nie należy ona do dziedziny prawa materialnego, nie jest warunkiem karalności czynu, lecz jedynie warunkiem wszczęcia postępowania. Przepisy określające tryb ścigania są przepisami procesowymi, niezależnie od tego czy znajdują się w kodeksie postępowania karnego czy w kodeksie karnym. [...] W procesie zbudowanym w oparciu o zasadę skargowości skarga uprawnionego oskarżyciela jest więc konieczna we wszystkich sprawach, bez względu na to czy chodzi o przestępstwo publicznoskargowe, czy przestępstwa ścigane z oskarżenia prywatnego. Nie ma pod tym względem żadnej różnicy między przestępstwami ściganymi skargą publiczną i skargą prywatną. [...] W naszym prawie wniesienie skargi prywatnej jest czynnością czysto procesową, a sama skarga jest aktem par exellence procesowym ${ }^{43}$.

${ }^{41}$ Nawiązanie do tej grupy przestępstw może być o tyle pomocne, że, cytując za I. Nowikowskim, „Istnienie przestępstw ściganych z oskarżenia prywatnego oraz związanego z tym odrębnego trybu postępowania budzi od lat kontrowersje w piśmiennictwie. Generalnie można wyróżnić dwie grupy poglądów. Pierwszy zakłada, że wyodrębnienie przestępstw ściganych z oskarżenia prywatnego jest swoistym atawizmem w rozwoju współczesnego prawa karnego. Pozostawienie w ustawach karnych tej grupy przestępstw jest traktowane jako niedokończenie procesu »upaństwowienia « prawa karnego. [...] Zgodnie zaś z zapatrywaniem drugim istnienie przestępstw ściganych z oskarżenia prywatnego ma racjonalne uzasadnienie. Podstawą do tego stwierdzenia jest m.in. teza, że choć ochrona przez prawo karne oznaczonych dóbr następuje w interesie publicznym, to jednak nie oznacza to konieczności marginalizowania albo pomijania interesu pokrzywdzonego. Warto w tym miejscu sięgnąć do poglądów M. Cieślaka, który stwierdził, że istnieją przestępstwa naruszające bezpośrednio interes indywidualny, a tylko pośrednio interes społeczny, ponieważ państwo chroni i sankcjonuje pewne interesy indywidualne. Zdaniem autora przykładem takiego przestępstwa jest zniesławienie. W konkluzji M. Cieślak stwierdził, że przy tego rodzaju przestępstwach zgoda pokrzywdzonego wyłącza zawsze społeczne niebezpieczeństwo. Tak więc fakt uprzedniej dobrowolnej zgody pokrzywdzonego powoduje, iż tym samym odpadł interes społeczeństwa" - I. Nowikowski, Interes społeczny jako powód zmiany trybu ścigania przestępstw z oskarżenia prywatnego (zagadnienia wybrane), „Teka Kom. Praw. — OL PAN, III” 2010, s. 150-151. W duchu pierwszej z przedstawionych tu koncepcji tłumaczy też wyodrębnienie przestępstw prywatnoskargowych T. Bojarski; zob. T. Bojarski, Karnoprawna ochrona nietykalności mieszkania jednostki, Lublin 1992, s. 161; idem, Uwagi o ściganiu z oskarżenia prywatnego i na wniosek, [w:] Współczesny polski proces karny. Księga ofiarowana Profesorowi Tadeuszowi Nowakowi, red. S. Stachowiak, Poznań 2002, s. 38-40; zob. też D. Gil, Postepowanie w sprawach z oskarżenia prywatnego w polskim procesie karnym, Warszawa 2011.

42 A. Marek, Stopień społecznego niebezpieczeństwa czynu jako podstawa warunkowego umorzenia postępowania, Toruń 1970, s. 114-115.

43 W. Daszkiewicz, Oskarżyciel w polskim procesie karnym, Warszawa 1960, s. 255-256, 260 ,

Nowa Kodyfikacja Prawa Karnego 43, 2017

(C) for this edition by CNS 
Nie wydaje się jednak, by tego rodzaju stwierdzenie, niewątpliwie pod względem zaszeregowania przepisów normujacych tryb ścigania do formalno- czy materialnoprawnych, niepodważalnie trafne, odpowiadało na pytanie, dlaczego jednak ustawodawca zdecydował się na wprowadzenie rozróżnień w tym zakresie. Czyżby to rozróżnienie na płaszczyźnie procesowej istniało bez swoich jakichkolwiek materialnoprawnych źródeł? ${ }^{44}$ Co od strony czysto proceduralnej miałoby je uzasadniać, skoro nie poszukujemy uzasadnienia na płaszczyźnie prawa materialnego?

Niewiele inaczej jednak problem postrzegany jest w pismiennictwie karnomaterialnym. R. Zawłocki w swojej monografii poświęconej społecznej szkodliwości pisze przykładowo, że

uznanie, że to społeczne wartości, a nie bieżące potrzeby społeczne i opinie wyznaczają ujemny ładunek społeczny czynu zabronionego, umożliwia stwierdzenie bytu i pełnego zakresu społecznej szkodliwości nie tylko w odniesieniu do przestępstw publicznoskargowych, lecz także prywatnoskargowych. Dóbr chronionych przepisami określającymi przestępstwa prywatnoskargowe nie cechuje pomniejszona ranga społeczna. Odnoszą się one, co prawda, do dóbr osobistych, ściśle związanych z konkretnym człowiekiem, jednak zamach na te dobra stanowi naruszenie wartości powszechnie w społeczeństwie uznanych. Specyfika omawianych dóbr nie polega na tym, że są one mniej ważne od innych, lecz na tym, że - z uwagi na ich charakter - osobie pokrzywdzonej daje się w tym przypadku prawo zainicjowania i określenia toku procedury karnej (możliwości pociągnięcia sprawcy do odpowiedzialności karnej). Oznacza to, że np. zniesławienie (zob. art. 212 § $1 \mathrm{KK}$ ) może zostać uznane za społecznie szkodliwe nawet w stopniu znacznym. Przedstawione rozwiązanie pozwala uwzględnić rzeczywiste zjawiska i wyłącza sztuczne ograniczenia w karnoprawnej ocenie czynów zabronionych, która winna opierać się na takiej samej zasadzie bez względu na ich rodzaj. Zatem można się zgodzić z W. Daszkiewiczem, iż tryb ścigania sprawców czynów zabronionych nie ma wpływu na ocenę społecznej szkodliwości ${ }^{45}$.

Zdaniem A. Marka społecznie szkodliwy charakter mają nie tylko czyny skierowane przeciwko dobrom ogólnym, lecz również przeciwko dobrom poszczególnych obywateli, którym prawo powinno tak samo zapewnić należytą ochronę ${ }^{46}$. E. Plebanek w tym samym tonie również podnosi, że w żadnym razie za kryterium podziału przestępstw na publiczno- i prywatnoskargowe nie można przyjmować odmienności stopnia społecznej szkodliwości.

rozstrzygające znaczenie w tym zakresie ma bezpośredni bądź tylko pośredni charakter naruszenia interesu publicznego przez czyn danego rodzaju. O trybie ścigania decyduje zatem w przypadku przestępstw ściganych z oskarżenia prywatnego przede wszystkim swoisty charakter chronionych przez nie dóbr i ujętych w normach sankcjonujących sposobach ich

${ }^{44}$ Szczególnie gdy weźmie się pod uwagę funkcjonalną podległość prawa karnego procesowego prawu materialnemu. Por. P. Kardas [w:] System Prawa Karnego Procesowego. Zagadnienia ogólne, t. I, cz. 1, red. P. Hofmański, Warszawa 2013, s. 578-672, 618-619.

45 R. Zawłocki, op. cit., s. 143.

46 A. Marek, W. Konarska-Wrzosek, Prawo karne, Warszawa 2016, s. 9; tak też. E. Kruk, Skarga w postepowaniu prywatnoskargowym, „Ius Novum” 2012, nr 4, s. 79. 
naruszeń nie zaś niewielki stopień ich społecznej szkodliwości w ujęciu generalno-abstrakcyjnym ${ }^{47}$.

Obrona tego rodzaju poglądu ma jednak sens o tyle, o ile wykazuje bezprzedmiotowość argumentacji za dopuszczalnością bezwarunkowego umorzenia postępowania w przypadku przestępstw prywatnoskargowych na podstawie znikomego stopnia ich społecznej szkodliwości, a do tych w istocie kwestii i dyskusji nad nimi toczonej jeszcze w poprzednim ustroju odwołuje się autorka ${ }^{48}$. Nie wymaga wszak szerszego dowodzenia, że czyny prywatnoskargowe pozostają przestępstwami, a więc pod względem wypełnienia warunku dostatecznego ładunku społecznej szkodliwości nie różnią się od innych czynów podlegających kryminalizacji, przynajmniej tak długo, jak długo opieramy tę ostatnią na kryteriach legitymizowanych $\mathrm{w}$ demokratycznym porządku prawnym ${ }^{49}$. Można również przytoczyć te stanowiska, które nie bez racji wskazują, że społeczna szkodliwość, oceniana na płaszczyźnie stanowienia prawa, w ogóle nie stanowi kategorii stopniowalnej ${ }^{50}$, a zatem jakiekolwiek wywody o mniejszych lub większych jej progach przy wyznaczaniu granicy ingerencji prawnokarnej są obciążone podstawowym błędem przesunięcia kategorialnego i mylenia jej istoty oraz funkcji z rolą, jaką odgrywa na poziomie stosowania ustawy karnej, a zatem korekty typu w rozumieniu art. $1 \S 2$ k.k. ${ }^{51} \mathrm{Z}$ drugiej strony nie da się przeoczyć faktu, który ujęty w sposób najbardziej banalny brzmiałby następująco: skoro ustawodawca podjął decyzję o zróżnicowaniu trybów ścigania, to jednak jakaś różnica pomiędzy nimi musi być dla niego uchwytna. Jednym z argumentów właśnie za istnieniem podejrzewanej różnicy jest choćby argument przytaczany przez A. Marka, mający w założeniu

47 E. Plebanek, Materialne określenie przestępstwa, Warszawa 2009, s. 153.

48 Zob. ibidem, s. 151-154 i przytoczona tam literatura.

49 O tym, że muszą one spełniać warunek przynajmniej naruszenia lub zagrożenia - i to bezpośredniego - dóbr prawnych przesądza właśnie ich tryb ścigania, uzależniony od skargi pokrzywdzonego, którego bez spełnienia wcześniejszego warunku — zgodnie z definicją legalną tego uczestnika postepowania z art. 49 k.p.k. — po prostu by nie było.

50 Zob. zwłaszcza M. Dąbrowska-Kardas, op. cit., s. 23-25, która wskazuje, że ustawodawca ocenia społeczne niebezpieczeństwo jedynie jako cechę obiektywną i niestopniowalną, wyrażającą się w naruszeniu lub zagrożeniu dobra prawnego, które istnieje lub nie. Inny argument oparty jest na uznaniu zasady nullum crimen sine periculo sociali za regułę — reguły zaś mogą być zrealizowane lub nie, lecz nie jest możliwa ich realizacja tylko w pewnym stopniu.

51 Tak np. A. Marek, dla którego ostatecznym argumentem za tożsamym poziomem społecznej szkodliwości czynów publiczno- i prywatnoskargowych jest fakt, że ostatecznie ustawodawca zdecydował się przyznać prokuratorowi w sprawie prywatnoskargowej możliwość wytoczenia oskarżenia z urzędu (A. Marek, Stopień społecznego..., s. 115). Natomiast przyjmując stopniowalność w tym zakresie, bez powoływania się na podobny nietrafny jednak argument, można tylko zauważyć, że jednak omawiane grupy przestępstw różnią się i na tym poziomie. R. Zawłocki stwierdza, że różnica pomiędzy nimi występuje nie tylko w odniesieniu do społecznej szkodliwości, lecz także wyróżnianego przez siebie społecznego niebezpieczeństwa i z reguły charakteryzuje je właśnie pomniejszony stopień obu kategorii. R. Zawłocki, op. cit., s. 390. 
jakoby przesądzać o jej braku. Możliwość objęcia ściąganiem przez prokuratora przestępstwa prywatnoskargowego, gdy — zgodnie z art. 60 § 1 k.p.k. „wymaga tego interes społeczny" — nie jest niczym innym jak wprowadzeniem rozwiązania na wypadek, gdyby w konkretnych okolicznościach indywidualnego przypadku różnica taka pomiędzy przestępstwem prywatnoskargowym a publicznoskargowym jednak nie powstała ${ }^{52}$. Jest to zatem korekta przewidziana dla sytuacji wyjątkowych, atypowych, co oznacza, że regułą pozostaje właśnie odmienność.

Podążając dalej tym tropem argumentacyjnym, da się też zauważyć, że zarówno „,swoisty charakter chronionych dóbr i sposobów ich naruszenia”, jak i „pośredni, a nie bezpośredni charakter naruszenia interesu społecznego", mające w miejsce różnic w społecznej szkodliwości decydować o charakterze rozpatrywanych przestępstw, stanowią jednak elementy nie tylko wiążące się z wartościowaniem czynów pod względem ich społecznej szkodliwości, lecz wręcz dla jej oceny kluczowe. Przecież - powracając raz jeszcze do sformułowań szanownego Jubilata — społeczna szkodliwość bez jej odniesienia do dóbr czy stosunków społecznych jest zawieszona w próżni. Ma ona też zawsze charakter relatywny, gdyż jej istota leży w możliwości wywołania szkody w określonych dobrach i interesach ${ }^{53}$. Jeżeli dalszymi okolicznościami decydującymi o sensie wyodrębniania typów prywatnoskargowych mają być: godzenie w dobra ściśle osobiste, konieczność pozostawienia możliwości osobistego uregulowania powstałego konfliktu oraz ograniczenia zbędnej ingerencji aparatu państwowego w sferę wolności jednostki, to całość przedstawia sobą wystarczającą podstawę do różnicowania samej ich społecznej szkodliwości. Nie jest to jednak różnica ilościowa - bo taką w rozumieniu jakiegoś subminimalnego, drastycznie odmiennego stopnia społecznej szkodliwości ze wskazywanych wcześniej powodów być nie może, lecz jakościowa, wyrażająca się właśnie w wysunięciu na pierwszy plan perspektywy indywidualistycznej ofiary przestępstwa $^{54}$. Słusznie tym razem konstatuje R. Zawłocki, że

52 Najprościej tłumaczy się tę przesłankę w następujący sposób — „interes społeczny w ściganiu przestępstw prywatnoskargowych zachodzi wówczas, gdy czyn przestępny godzi bezpośrednio nie tylko w chronione prawem interesy pokrzywdzonego, ale także w dobra ogólne" — tak. m.in. K.T. Boratyńska, A. Górski, A. Sakowicz, Kodeks postępowania karnego. Komentarz, wyd. 4, Warszawa 2012; M. Czekaj, Ingerencja prokuratora w sprawach o przestepstwa prywatnoskargowe, Prok. i Pr. 1999, nr 7-8, s. 48; K. Marszał, Ingerencja prokuratora w ściganie przestęstw prywatnoskargowych $w$ polskim procesie karnym, Warszawa 1980, s. 32. Co interesujące - w literaturze procesowej tłumaczy się też wystąpienie społecznego interesu „okolicznościami sprzyjającymi powstaniu zwiększonej społecznej szkodliwości” - por. P. Hofmański, E. Sadzik, K. Zgryzek, Kodeks postępowania karnego. Komentarz do artykułów 1-296, t. 1, Warszawa 2011, s. 432.

53 T. Kaczmarek, Społeczne niebezpieczeństwo..., s. 68-69.

54 Taki też charakter różnicy pozostanie uchwytny, gdy omawiane tu kryteria wprowadzone przez T. Kaczmarka zastąpi się innymi kryteriami oceny społecznej szkodliwości czynu, np. wyszczególnionymi przez R. Zawłockiego: kryterium interesu władzy, interesów społeczeństwa, kryterium ,probabilistyczno-utylitarno-celowościowe”, kryterium dobra prawnego, reguł społecznej tolerancji, obiektywnej antyspołeczności i sprawiedliwej odpłaty. Por. R. Zawłocki, op. cit. 
Jakkolwiek kryterium przedstawionego podziału sprowadza się do formalnie rozróżnianego trybu ścigania przestępstwa, to jednak jego ontologiczna podstawa związana jest, z przeprowadzoną przez prawodawcę, polityczno-kryminalną oceną uprawnienia do ścigania danego przestępstwa w kontekście dobra prawnego chronionego przez przepis je określający ${ }^{55}$.

Podtrzymując zatem poczynione na wstępie zastrzeżenie, że tendencje prywatyzacyjne nie uchylają konieczności poprzedzenia decyzji legislacyjnej odniesieniem się do społecznej szkodliwości, można wysunąć wniosek, że ich nasilanie się może znaleźć odbicie nie tyle w bezpośredniej dekryminalizacji już istniejących czynów, ile w poszerzaniu kręgu przestępstw niepodlegających dotychczasowemu publicznoprawnemu trybowi ścigania. Celowo zresztą zostały one w tym momencie określone wyłącznie od strony negatywnej — jako że nie stanowiłyby prostego poszerzenia zakresu przedmiotowego postepowania prywatnoskargowego z zachowaniem wszystkich jego dotychczasowych rozwiązań, lecz raczej wydobycie z niego elementów dyspozycyjności skargą i konsensualności ${ }^{56}$. Byłby

55 R. Zawłocki, Klasyfikacja przestępstw, [w:] System..., red. R. Dębski, s. 133.

56 Skądinąd dla tego ostatniego mogłyby one oznaczać ostateczny zmierzch, gdyż już nic nie uzasadniałoby jego dalszego utrzymywania wobec szeregu kontrowersji, jakie budzi ono właśnie ze względu na pozycję pokrzywdzonego w procesie. W zarzutach kierowanych wobec tego trybu wskazuje się, że postępowanie prywatnoskargowe nie tyle stanowi o uprzywilejowaniu pokrzywdzonego, ile przenosi na niego cały ciężar prowadzenia sprawy, nie dysponując ani możliwościami organów ścigania, ani nie mogąc — poza ograniczonym zakresem art. 488 — korzystać z efektów ich pracy śledczej, musi on sam wyszukać, utrwalić i przedstawić dowody. Można by zatem równocześnie rozwiązać dwa problemy — zlikwidować postepowanie prywatnoskargowe i wzmocnić elementy konsensualne oraz kompensacyjne, także jako odpowiedź na nadmierną kryminalizację. $\mathrm{Z}$ drugiej jednak strony propozycje zwiększenia właśnie katalogu przestępstw prywatnoskargowych są zgłaszane w piśmiennictwie jako rozwiązanie wzmacniające kontradyktoryjność, pozycję procesową stron oraz efektywność wymiaru sprawiedliwości — „Postępowanie w sprawach prywatnoskargowych jest postępowaniem, na które strony postępowania mają największy wpływ. Pełna swoboda przy wnoszeniu skargi oraz szerokie możliwości jej wycofania dowodzą, że jest to postępowanie, w którym strony mogą, w nieporównywalnym do innych trybów zakresie, dysponować przedmiotem procesu, co też może zasadnie sugerować podobieństwo do procesu cywilnego. [...] Jeśli przedstawiona tu ogólna ocena trybu prywatnoskargowego i jego rozwiązań wypada pozytywnie, to implikuje to jednocześnie stanowisko o potrzebie dalszego obowiązywania tego trybu w systemie prawa. Taka opinia z kolei nakazuje zadać pytanie o zasadność wykorzystania postępowania prywatnoskargowego w szerszym zakresie. Sugerowana wcześniej ostrożność przy poszerzaniu katalogu przestępstw prywatnych nie oznacza jednocześnie krytyki takich propozycji, które przecież w doktrynie od dawna się pojawiają. Więcej przestępstw ściganych w trybie z oskarżenia prywatnego oznaczałoby częściowe odciążenie organów ścigania oraz uproszczenie wielu postępowań sądowych. Przykłady chociażby przestępstw niealimentacji czy naruszenia miru domowego wydają się być dobrymi propozycjami, ponieważ zasadniczo mają charakter prywatny i nie są skomplikowane, a zatem mogłyby odbywać się bez postępowania przygotowawczego. [...] Gdy zaś owa prostota i brak skomplikowania sprawy zacznie być podawana w wątpliwość, a pozostaje tylko prywatny charakter przestępstwa, to tak naprawdę jesteśmy już bardzo blisko pytania o jego ewentualne ściganie na wniosek. Dlatego też poszerzenie zbioru przestępstw ściganych w ramach »procesu prywatnego« zasługuje na aprobatę, niemniej jednak decyzja co do konkret- 
to zresztą kierunek o tyle zrozumiały i zasługujący na akceptację, że dość zgodnie łączący gwarancyjne znaczenie dotychczasowych zasad prawa karnego z postulatami poszanowania podmiotowości ofiary i sprawcy przestępstwa, zarazem bez idealizmu skrajnych nurtów sprawiedliwości naprawczej oraz odpowiadający czysto już praktycznym potrzebom odciążenia wymiaru sprawiedliwości. Daleko byłoby jeszcze do uznania, że możemy mieć w tych przypadkach do czynienia z kryminalizacją, którą można by określić jako „zawieszoną”, gdyż taka konstrukcja mogłaby wywoływać wątpliwości ze względu na zasady gwarancyjne prawa karnego, lecz sam element możliwości współdecydowania przez pokrzywdzonego i oskarżonego o bycie przestępstwa musiałby być już uwzględniony na poziomie karalności, a być może jednak nawet na płaszczyźnie znamienności typu, co skądinąd otwierałoby ciekawe pole do pewnych analogii, np. ze zgodą dysponenta dobrem prawnym.

Kolejne kryterium oceny społecznej szkodliwości, związane z wartościowaniem zachowań pod kątem określonej wagi i stopnia dla interesów chronionych przez prawo karne, wydaje się mniej podatne na wpływy prywatyzacji, jednak tylko tak długo, jak długo nie wnikniemy w istotę zasadniczego, tworzącego je elementu, czyli dobra podlegającego prawnokarnej ochronie. Nie jest przypadkiem, że teorie sprawiedliwości naprawczej, które otworzyły drzwi do przenikania rozwiązań prywatnoprawnych, zbiegły się w czasie z poszukiwaniem konkurencyjnych wobec tradycyjnego ujmowania przedmiotu ochrony prawnokarnej propozycji jego zdefiniowania, rozwijanych w kierunku skoncentrowania się na osobistym wymiarze pokrzywdzenia, naruszenia dobra jednostki, a nie zbiorowości. Trafnie wartość tego rodzaju koncepcji, jak choćby personalistycznej nauki o dobrach prawnych W. Hassemera ${ }^{57}$, dostrzega T. Kaczmarek w odpowiedzi na swoistą klęskę urodzaju w obszarze ochrony dóbr uniwersalnych, kolektywnych, a jednocześnie w nastawieniu na zapobieżenie procesowi nadmiernego rozszerzania przedpola karalności.

W tej koncepcji dobra powszechne zostają podporządkowane dobrom indywidualnym, jako że w rzeczywistości za tzw. dobrami ogółu kryje się zawsze interes, korzyść dla pojedynczego człowieka. Dobra takich agregatów, jak państwo, społeczeństwo, porządek prawny, obrót gospodarczy czy środowisko naturalne, samodzielnie nie istnieją. Miarą dóbr pozostaje jednostka. Owe zbiory kolektywne stają się dobrami prawnymi, jeśli umożliwiają człowiekowi jego samorozwój i służą jego samorealizacji. [...] Założona w nich funkcjonalizacja interesów zbiorowych poprzez ich odniesienie do pojęcie osoby oraz połączenie na zasadzie umowy społecznej uprzednio wyznaczonych dóbr prawnych z konstytucyjną ochroną praw i wolności,

nych przestępstw wymagałaby głębokiej analizy problemu". T. Bergel, Odmienności postępowania prywatnoskargowego, [w:] Postepowanie karne a inne postepowania represyjne, red. P. Czarnecki, Warszawa 2016, s. 142.

57 W. Hassemer, Theorie und Soziologie des Verbrechens. Ansätze zu einer praxiorientierten Rechtsgutslehre, Frankfurt am Main 1973; idem, Grundlinien einer personalen Rechtsgutlehre, [w:] idem, Strafen im Rechtsstaat, Baden-Baden 2000, s. 160 n. 
jeśli nawet nie gwarantuje w pełni ścisłej delimitacji dóbr podlegających prawnej ochronie, to z pewnością dobrze punktuje problemy i wyznacza kierunek ich rozwiązywania ${ }^{58}$.

Odejście od „uspołeczniania” dóbr chronionych przez prawo karne nie tylko stanowi reakcję na wątpliwości legitymizacyjne, które budzi przydawanie tego waloru coraz bardziej zdematerializowanym interesom zbiorowym. W dobie interkulturowości podobne zastrzeżenia muszą już pojawić się co do samej tezy, że istnieją jakieś nadrzędne, wspólne interesy całej zbiorowości. Co najwyżej mówić można o potrzebie powszechnego uznania poszczególnych interesów jednostkowych $^{59}$. W tym miejscu zresztą po raz kolejny można odnieść się do spostrzeżeń T. Kaczmarka, który wielokrotnie podkreślał, że nie powinno się sprowadzać materialnej cechy przestępstwa do solidarystycznych fikcji ${ }^{60}$.

Temat prywatyzacji prawa karnego budzić może wszelkiego rodzaju kontrowersje, jest też wystarczająco świeży, by stanowiska doktryny w tym względzie dopiero się kształtowały. Już jednak trwałe miejsce, które znalazła w prawie karnym kompensacja wraz z poglądem, że zaspokojenie potrzeby sprawiedliwości nie musi przebiegać jedynie na drodze sformalizowanej ingerencji państwa i jego aparatu oraz coraz wyraźniejszy wpływ nieinstytucjonalnych uczestników procesu na jego prowadzenie, wskazuje, że spodziewanie się dalszych zmian w tym kierunku zyskuje uzasadnienie ${ }^{61}$. Pytaniem pozostaje, w jakim stopniu znajdą one swoje odbicie na poziomie stanowienia norm sankcjonowanych. Można spodziewać się, że ich celem powinno być powstrzymanie coraz mniej chyba kontrolowanego rozszerzania kryminalizacji na przedpole, a tym samym zawężenie grupy czynów zagrożonych karą. Aby jednak móc sensownie wysuwać tego rodzaju oczekiwania, należy najpierw przeanalizować oddziaływanie tendencji prywatyzacyjnych na formułę społecznej szkodliwości, albowiem to jej ocena przede wszystkim decyduje i decydować powinna o zasadności karania.

\section{Tendencies to privatise criminal law and recognition of social harm as the basis of criminalisation}

\section{Summary}

In the changing social reality, the classic scheme of criminal liability with its characteristic relationship between the state and the parties involved no longer meets the needs of effective but fair response to the criminal acts. Consequently, the object of the scientific and legislative debate

58 T. Kaczmarek, Dobro prawne..., s. 278-279.

59 Zob. B. Wojciechowski, Interkulturowe prawo karne. Filozoficzne podstawy karania w wielokulturowych społeczeństwach demokratycznych, Torun 2009.

60 T. Kaczmarek, Społeczne niebezpieczeństwo..., s. 69. Również idem, Dobro prawne..., s. 266.

61 Co oczywiście w najmniejszym stopniu nie musi oznaczać bezrefleksyjnej aprobaty każdej formy i intensywności przenikania do prawa i procedury karnej elementów prywatnych czy prywatnoprawnych. 
becomes the phenomenon of privatisation (also called in the literature the civilization phenomenon) of criminal law. With the acceptance of the assumption that the basis for the criminalisation of any conduct must be its social harmfulness, the paper concerns the problem of the impact which re-evaluation of the role of the state and the concept of discourse and restorative justice have on the above mentioned criterion. The author tries to demonstrate that these phenomena and introduction to the criminal law elements of private law must be reflected also with respect to the understanding and evaluation of social harmfulness.

Keywords: social harmfulness, privatisation of criminal law, criminalisation, legal good, offences prosecuted on private accusation. 